\title{
Imidacloprid Effects on Root Growth, Photosynthesis, and Water Use of Cucumber in the Greenhouse
}

\author{
Byron Wallace ${ }^{1}$ \\ Plant Science Research Center, Auburn University, AL 36849 \\ Robert C. Ebel ${ }^{2,3}$ and Joseph Kemble ${ }^{2}$ \\ Department of Horticulture, 101 Funchess Hall, Auburn University, \\ AL 36849-5408
}

Additional index words. Cucumis sativus

Imidacloprid [1-(6-chloro-3-pyridylmethyl) - $N$-nitroimidazolidin-2-ylideneamine] (Bayer Corp., Kansas City, Mo.) is a new insecticide that is highly effective against a wide range of economically important sucking insects for ornamental crops grown in greenhouses (Mullins, 1993). A few reports show that imidacloprid can be phytotoxic (Dewar et al., 1997; Ebel et al., 2000; Natick et al., 1996), but the conditions that predispose plants to phytotoxicity are not known. Marathon ${ }^{\circledR}(1 \%$ granular formulation) is the only formulation currently labeled for greenhouse-grown ornamentals; however, the company is seeking to expand the label to include greenhousegrown vegetable crops. Marathon ${ }^{\circledR}$ applied to tomato (Lycopersicon esculentum Mill.) and cucumber (Cucumis sativus L.) plants grown in a glasshouse caused leaf chlorosis, marginal necrosis, leaf cupping, and altered foliar nutrition (Ebel et al., 2000). Although these symptoms were similar to those of calcium deficiency, foliar calcium was not deficient. The following study was conducted to determine whether imidacloprid affects other aspects of growth and development, including root growth, water use, and photosynthesis.

'Turbo' cucumber seeds were sown on 10 July 1998 in 7.3-cm-diameter, 85-cm-high, clear plastic cylinders, filled with fritted clay (Moltan Plus, Middelton, Tenn.) that had been drenched in an aqueous solution of $3.7 \mathrm{~g} \cdot \mathrm{L}^{-1}$ dolomitic limestone. The cylinders were placed upright in three temperature-control boxes (Miller et al., 1995) that kept maximum/minimum root temperatures at $27.5 / 20.4{ }^{\circ} \mathrm{C}$, respectively. The experiment was conducted in a glasshouse, where air temperatures averaged $28^{\circ} \mathrm{C}$ day $/ 22^{\circ} \mathrm{C}$ night and relative humidity

\footnotetext{
Received for publication 23 Aug. 1999. Accepted for publication 21 Jan. 2000. The cost of publishing this paper was defrayed in part by the payment of page charges. Under postal regulations, this paper therefore must be hereby marked advertisement solely to indicate this fact.

${ }^{1}$ Assistant Superintendent.

${ }^{2}$ Assistant Professor.

${ }^{3}$ To whom reprint requests should be addressed. Email: rcebel@acesag.auburn.edu
}

was $>40 \%$ throughout the experiment. Seedlings were fertilized with $280 \mathrm{~mL} /$ cylinder of $\mathrm{N}$ at 80 to $140 \mathrm{mg} \cdot \mathrm{L}^{-1}$ using $20 \mathrm{~N}-4.4 \mathrm{P}-16.6 \mathrm{~K}$ (Scotts-Sierra Horticultural Products Co., Marysville, Ohio) on 16 July, 20 July, 23 July, and 4 Aug. Plants were watered daily.

The experimental design was a randomized complete block with six blocks and one plant per treatment per block. Marathon ${ }^{\circledR}$ was applied on 27 July 1998 to the soil medium at $0,5,10$, and $20 \mathrm{mg}$ a.i. per cylinder. Evapotranspiration was measured daily between 1930 and $1945 \mathrm{HR}$ by weighing each cylinder. Immediately after weighing, water was added back to each cylinder up to the weight that existed the day before Marathon ${ }^{\circledR}$ was applied. Chlorosis of leaves was measured every 2 to 3 d using a SPAD light meter (model 502, Minolta, Osaka, Japan). Photosynthesis of the four oldest leaves was measured at 1- to 3-d intervals using a portable photosynthesis system (model LI-6400, LI-COR, Lincoln, Nebr.). Root density was estimated 0,7 , and $15 \mathrm{~d}$ after treatment (DAT) by counting the number of individual roots that intersected lines spaced $10 \mathrm{~cm}$ apart and perpendicular to the long axis of each cylinder.

The experiment was terminated 15 DAT. All leaves were excised from the stems and total leaf area was measured using a leaf area meter (model LI-3100, LI-COR). Necrotic areas of leaves were excised, and total area of the undamaged portion was determined. Roots were extracted from the cylinders and the soil medium removed by rinsing in running water. Root samples were dried in a forced-air drying oven at $80^{\circ} \mathrm{C}$ for $96 \mathrm{~h}$, weighed, and placed in a muffle furnace for $24 \mathrm{~h}$ at $330^{\circ} \mathrm{C}$. The weight of the fritted clay that was not rinsed from the roots was determined and subtracted from the root dry weight. Leaves and shoots were dried for $48 \mathrm{~h}$ in a forced-air drying oven at $80^{\circ} \mathrm{C}$ and weighed.

Data were analyzed using the General Linear Models procedure of the Statistical Analysis System and as a split-plot over time, where appropriate (SAS Institute, 1998). There was no significant interaction over time for chlorosis, water use, or photosynthesis. Treatment means were separated using the Waller-
Duncan k ratio $t$ test. Chlorosis developed in the oldest leaves $10 \mathrm{~d}$ after treatment, with the SPAD readings averaging $40 \mathrm{a}, 39 \mathrm{a}, 35 \mathrm{~b}$, and $30 \mathrm{c}$ (mean separation at $P<0.05$ ) for $0,5,10$, and $20 \mathrm{mg} /$ pot a.i., respectively, until the end of the experiment. The treatments did not affect photosynthetic flux, intercellular $\mathrm{CO}_{2}$, stomatal conductance, or transpiration on any of the leaves measured, including the oldest leaf, which was the most chlorotic and necrotic on the plant, or water use, total leaf area per plant, or shoot, root, and total plant dry weight. Marginal necrosis at the end of the experiment was $0 \mathrm{a}, 4.8 \mathrm{~b}, 6.7 \mathrm{c}$, and $9.8 \mathrm{~d}$ percentage of the leaf area for the $0,5,10$, and $20 \mathrm{mg} /$ pot a.i. treatments, respectively.

Development of leaf chlorosis and marginal necrosis was similar to that in the first study (Ebel et al., 2000). However, unlike the first study, total plant leaf area and shoot dry weight were not affected, even at the same rates of Marathon ${ }^{\circledR}$ used previously. Differences in plant response between the two studies were due to one or more differences in growing conditions. The plants in the first study were grown in smaller pots $(0.55 \mathrm{~L})$, as opposed to $14 \mathrm{~L}$ in the current study. Plants wilted before watering in the first study, whereas plants in the current study did not. The pots in the first study were not in a temperature-controlled chamber; thus, roots were probably exposed to higher temperatures. The soil medium in the two studies was also different. Additional studies need to be conducted to determine what growing conditions predispose plants to develop phytotoxicity symptoms. Nevertheless, the current study demonstrates that although imidacloprid can cause leaf chlorosis and marginal necrosis, whole plant growth, photosynthesis, or water use may not be affected.

\section{Literature Cited}

Dewar, A.M., F. Westwood, K.M. Bean, L.A. Haylock, and R. Osborne. 1997. The relationship between pellet size and the quantity of imidacloprid applied to sugar beet pellets and the consequences for seedling emergence. Crop Prot. 16:187-192.

Ebel, R.C., B. Wallace, and C. Elkins. 2000. Phytotoxicity of the systemic insecticide imidacloprid on tomato and cucumber in the greenhouse. HortTechnology 10:144-147.

Miller, M.S., M.R. Owsley, and C.E. Elkins. 1995. A low-cost system for root temperature control in protected-culture studies. In: Abstracts of Tech. Papers, Annu. Mtg., Southern Branch Amer. Soc. Agron., New Orleans, La., 29 Jan.2 Feb.

Mullins, J.W. 1993. Imidacloprid. A new nitroquanidine insecticide, Ch. 13, p. 183-198. In: S.O. Duke, J.J. Menn, and J.R. Plimmer (eds.). Pest control with enhanced environmental safety. Amer. Chem. Soc., Washington, D.C.

Natick, E.T., J.C. Palumbo, and C.E. Engle. 1996. Effects of imidacloprid on colonization of aphids and silverleaf whitefly and growth, yield, and phytotoxicity in cauliflower. Southwestern Entomologist 21:283-292.

SAS Institute. 1988. SAS/STAT user's guide, release 6.03. SAS Inst., Cary, N.C. 